J. Math. and Its Appl.

E-ISSN: 2579-8936

P-ISSN: $1829-605 \mathrm{X}$

Vol. 15, No. 1, Maret 2018, 41-54

\title{
Analisis Hubungan Antara Financial Distress dan Keputusan Kebijakan Dividen Omisi Perusahaan Manufaktur
}

\author{
Dwi Putri Antika ${ }^{1}$, Mohamat Fatekurohman ${ }^{2}$, Dian Anggraeni ${ }^{3}$ \\ ${ }^{1,2,3}$ Fakultas Matematika dan Ilmu Pengetahuan Alam (FMIPA), Universitas Jember \\ Jl. Kalimantan No. 37, Kampus Tegalboto, Sumbersari, Jember, Jawa Timur 68121 \\ dwiantika1804@gmail.com
}

\begin{abstract}
Abstrak
Financial distress adalah kondisi dimana perusahaan mengalami kerugian atau kehilangan, namun belum sampai dikatakan bangkrut. Kondisi yang paling mudah dilihat dari perusahaan yang mengalami financial distress adalah dari keputusan dividen omisi perusahaan. Tujuan dari penelitian ini adalah untuk mengetahui pengaruh dari rasio keuangan seperti likuiditas, leverage, profitabilitas, free cash flow, dan size terhadap durasi waktu antara perusahaan mengalami financial distress dan kemunculan dividen omisi dengan model Cox extended yang diinteraksikan dengan fungsi waktu dan dungsi Heaviside dan untuk mengetahui keberlangsungan perusahaan untuk membagikan dividen. Pada penelitian ini data yang digunakan adalah data rasio keuangan perusahaan manufaktur periode 2016 yang terdaftar di BEI yang telah membagikan dividen selama minimal tiga tahun berturut-turut. Data yang diperoleh dianalisis dengan mendeskripsikan karakteristik setiap variabel, estimasi fungsi survival menggunakan plot Kaplan-Meier, uji perbedaan kurva survival dengan uji Log-Rank, pembentukan model Cox extended dengan fungsi waktu dan fungsi heaviside dan dipilih model terbaik dengan melihat nilai AIC. Hasil dari penelitian ini adalah diperoleh model terbaik Cox extended dengan fungsi heaviside. Variabel yang signifikan adalah profitabilitas (Return on Asset), dan perusahaan yang memiliki profitabilitas yang lebih besar dari 5,98\% memiliki risiko mengalami omitted dividend $21 \%$ kali lebih kecil daripada perusahaan dengan profitabilitas rendah.
\end{abstract}

Kata Kunci: Cox Extended, Dividen Omisi, Financial Distress, Rasio Keuangan

\begin{abstract}
Financial distress is a condition which the company declared to lose but has not been bankrupt yet. The easiest visible condition of companies experiencing financial distress is the decision of omitted dividend. The purpose of this research are to find out time survival of companies to omit dividend payments later and the influence of liquidity, leverage, profitability, free cash flow, and size on the duration of time between companies experiencing financial distress and the decision of omitted dividend with Cox extended model interacted with the function of time and heaviside function. In this study the data used is the financial ratios of manufacturing companies in the period 2016 listed on the IDX that has been distributing dividends for at least three years in a row. The data obtained were analyzed by describing the characteristics of each variable, estimating survival function
\end{abstract}


using the Kaplan-Meier plot, testing the survival curve difference with Log-Rank test, forming the extended Cox model with the function of time and heaviside function and selected the best model by looking at the AIC value. The result of this research shows that the best model with heaviside function. A significant variable is profitability (Return on Asset). It means risk of companies with high profitability having omitted dividends $21 \%$ less than low profitability.

Keywords: Cox Extended, Omitted Dividend, Financial Distress, Finance Ratio

\section{Pendahuluan}

Suatu perusahaan memerlukan modal untuk menjamin kelangsungan hidup perusahaan. Investor sebagai calon pemberi modal juga mengharapkan keuntugan dengan melakukan call option yakni saat harga saham mencapai maksimum [3]. Salah satu kebijakan penting perusahaan yang dapat mempengaruhi investor adalah kebijakan dividen. Kebijakan dividen merupakan keputusan apakah laba yang diperoleh perusahaan akan dibagikan kepada pemegang saham sebagai dividen atau ditahan dalam bentuk laba untuk pembiayaan investasi dimasa mendatang. Perusahaan mungkin saja dapat melaksanakan pembayaran dividen sesuai kebijakan awal atau memutuskan untuk memotong bahkan menghapuskan pembayaran dividen tunai untuk pertama kalinya (dividen omisi) [8]. Persoalan yang terkait dengan penurunan dan penghapusan dividen berada dalam kasus financial distress [6]. Kondisi yang paling mudah untuk dilihat apakah perusahaan dalam kondisi financial distress adalah perusahaan melakukan penghapusan pembayaran dividen [1]. Keputusan perusahaan untuk melakukan dividen omisi dapat disebabkan berbagai faktor.

Adapun dalam ilmu statistika, durasi waktu antara perusahaan mengalami financial distress hingga mengalami kejadian (omit) dapat diprediksi menggunakan analisis survival. Model analisis survival adalah model yang berkaitan dengan menguji panjang interval waktu antara masa transisi. Metode yang digunakan dalam penelitian ini adalah model Cox nonproportional hazard. Kelebihan model ini adalah tidak harus memiliki fungsi dari distribusi parametrik dan untuk mengatasi adanya variabel yang tidak memenuhi asumsi proportional hazard. Penelitian sebelumnya dilakukan oleh Leclere (2000), berdasarkan hasil penelitiannya, data keuangan 652 perusahaan dari sektor manufaktur, ritel, tambang, dan nonfinansial dengan prediktor yang diduga penting antara lain likuiditas, free cash flow, leverage, profitabilitas, dan size. Hasil yang didapatkan, variabel-variabel yang signifikan yaitu profitabilitas dan size perusahaan.

Penelitian terkait kasus financial distress dengan dividen omisi juga perlu dilakukan di negara berkembang seperti di Indonesia. Hal ini dikarenakan permasalahan terkait dengan kebijakan dividen dan faktor-faktor yang mempengaruhi perubahan kebijakan tersebut menjadi 
lingkup bahasan yang penting di bidang keuangan. Adapun pada penelitian ini bertujuan untuk memodelkan durasi waktu antara perusahaan mengalami financial distress dan kemunculan dividen omisi (event) menggunakan model Cox extended dengan fungsi waktu $g(t)=\log (t)$ dan fungsi heaviside untuk menentukan hubungan keeratan (kesignifikansian) antara variabel dependen dan variabel independen.

Penelitian dilakukan pada perusahaan yang berasal dari sektor manufaktur, sebanyak 144 perusahaan dari sektor manufaktur 2016 yang terdaftar di Bursa Efek Indonesia (BEI). Sektor manufaktur dipilih karena memiliki banyak sub sektor dan karakter yang sama yakni bergerak dalam hal produksi. Pengamatan dilakukan selama 7 tahun mulai 2010 sampai 2016. Prediktor yang diduga berpengaruh antara lain likuiditas, leverage, profitabilitas, free cash flow, dan size.

\section{Metode Penelitian}

\subsection{Data dan Sumber Data}

Sumber data yang digunakan dalam penelitian ini adalah data sekunder yang diunduh melalui website www.idx.co.id dan www.sahamok.com. Data yang diperoleh sudah diolah oleh pihak pengumpul data primer serta melalui studi pustaka yang ada hubungannya dengan masalah yang dihadapi dan dianalisis, disajikan dalam bentuk informasi. Data sekunder yang diperlukan antara lain sebagai berikut:

a. Laporan keuangan perusahaan / laporan tahunan perusahaan

b. Tanggal pengumuman pembagian dividen

Pada kasus ini variabel terikat $(Y)$ adalah lamanya waktu keberlangsungan perusahaan yang mengalami financial distress hingga melakukan perubahan kebijakan dividen yakni omisi pembayaran dividen tunai. Sedangkan variabel bebas $(X)$ yang digunakan adalah:

1. Likuiditas $\left(X_{1}\right)$

Likuiditas adalah current ratio/current asset to current liabilities yang meupakan kemampuan perusahaan memenuhi hutang jangka pendek dengan menggunakan aktiva lancarnya [4].

$$
\text { Current ratio }(C R)=\frac{\text { Aset lancar }}{\text { kewajiban lancar }} \times 100 \%
$$

\section{Leverage $\left(X_{2}\right)$}

Leverage dapat diproksikan sebagai total total liabilitas jangka panjang terhadap total ekuitas [4].

Long term debt to equity ratio

$$
=\frac{\text { total hutang jangka panjang }}{\text { total pkuitas }} \times 100 \%
$$


3. Profitabilitas $\left(X_{3}\right)$

Rasio pendapatan adalah rasio untuk menilai kemampuan perusahaan dalam mencari keuntugan. Rasio pendapatan dicari dengan menggunakan ROA (Return on Asset) [4].

$$
\begin{aligned}
& \text { ROA } \\
& =\frac{\text { Laba Bersihh }}{\text { Tntal Aset }} \times 100 \%
\end{aligned}
$$

4. Free Cash Flow $\left(X_{4}\right)$

Dinyatakan sebagai rasio free cash flow dibagi dengan total aktiva. Menurut Kasmir (2014),

Free cash flow dihitung dengan rumus:

$$
F C F=\frac{\text { Arus kas operasi-Belanja Modal }}{\text { Total Aktiva }} 100 \%
$$

5. Ukuran Perusahaan $($ size $)\left(X_{5}\right)$

Besarnya nilai aset yang digunakan sebagai tolak ukur, harus disederhanakan dengan transformasi ke dalam bentuk logaritma natural [7].

$$
\text { size }=\ln (\text { Total Aset) }
$$

2.2 Langkah-langkah Penelitian

1. Metode Dokumenter

Mengumpulkan seluruh data sekunder. Pengumpulan data dilakukan pada perusahaan manufaktur yang tidak delisting dan telah membagikan dividen selama 3-5 tahun berturutturut. Data diperoleh dari web Bursa Efek Indonesia dan berupa data rasio keuangan yang diperoleh dari laporan keuangan atau tahunan perusahaan selaman periode 2010-2016. Data rasio keuangan yang digunakan seperti likuiditas (current ratio), leverage (long-term debt to equity), profitabilitas (return on asset), free cash flow, dan size ( $\ln$ (Total Aset )).

2. Analisis Deskriptif Karakteristik

Menganalisis karakteristik variabel-variabel yang mempengaruhi perubahan kebijakan pembayaran dividen perusahaan yaitu menunjukan subjek (perusahaan) yang tersensor dan tidak tersensor. Perusahaan dikatakan tersensor jika perusahaan tetap membagikan dividen sampai waktu pengamatan berakhir yakni sampai tahun 2016. Perusahaan dikatakan tidak tersensor jika perusahaan mengalami event yakni melakukan dividen omisi. 
3. Membuat Plot Fungsi Survival setiap Variabel dan Uji Log-Rank Menggunakan Program R

Estimasi fungsi survival dilakukan pada semua variabel dengan menggunakan metode Kaplan-Meier. Selanjutnya dilakukan uji Log-Rank untuk menguatkan kesimpulan dari hasil plot tentang ada tidaknya perbedaan survival antar kelompok pada setiap variabel.

4. Melakukan Uji Asumsi Proportional Hazard Menggunakan Uji Goodnes of fit (GOF) dan Time-Dependent Variable

Pada tahap ini, menggunakan variabel waktu saling bebas dalam model Cox extended dengan membuat interaksi antar variabel bebas dengan waktu survival kemudian lihat nilai signifikansinya. Asumsi proporsional terpenuhi bila nilai $p>0,05$. Uji asumsi juga menggunakan goodness of fit test, caranya adalah dengan melihat nilai $p$ (Chi-square). Jika nilai $p>0,05$ maka asumsi proporsional terpenuhi [5].

5. Memodelkan Waktu Ketahanan Perusahaan dan Memilih Model Terbaik

Pada tahap ini dibentuk model Cox extended dengan fungsi waktu dan fungsi heaviside. Variabel bebas yang tidak memenuhi asumsi proportional hazard diinteraksikan dengan fungsi waktu $g(t)=\log (t)$ dan fungsi heaviside. Variabel yang signifikan akan dimasukkan kedalam model. Uji kesignifikanan dilakukan dengan uji serentak (Likelihood ratio) dan uji parsial (Uji Wald Chi-square). Selanjutnya, dilakukan pemilihan model terbaik dengan membandingkan nilai AIC. Model terbaik ialah model dengan nilai AIC terkecil [2].

\section{Hasil dan Pembahasan}

Dari 144 perusahaan dari sektor manufaktur 2016, diperoleh sebanyak 62 perusahaan yang masuk pengamatan (telah membayarkan dividen selama minimal 3 tahun berturut-turut). Tipe penyensoran yang digunakan adalah penyensoran tipe III dimana objek masuk ke dalam pengamatan dalam waktu yang berbeda-beda.

\subsection{Analisis Deskriptif}

Perusahaan dikatakan tersensor karena perusahaan bertahan membayarkan dividen hingga waktu pengamatan berakhir sedangkan perusahaan dikatakan tidak tersensor karena perusahaan melakukan dividen omisi. Setelah diamati diperoleh 21 perusahaan memutuskan melakukan dividen omisi dan 41 perusahaan memutuskan untuk tetap membagikan dividen. Berikut analisis deskriptif untuk data kontinyu yang ditunjukkan pada Tabel 1. 
Tabel 1. Analisis Deskriptif Data Kontinyu

\begin{tabular}{lcccc}
\hline Prediktor & $\begin{array}{c}\text { Varians } \\
\text { (tahun) }\end{array}$ & $\begin{array}{c}\text { Mean } \\
\text { (tahun) }\end{array}$ & $\begin{array}{c}\text { Min } \\
\text { (tahun) }\end{array}$ & $\begin{array}{c}\text { Max } \\
\text { (tahun) }\end{array}$ \\
\hline $\begin{array}{l}\text { Waktu } \\
\text { Ketahanan }\end{array}$ & 6,221 & 4,484 & 1 & 7 \\
Perusahaan & & & & \\
\hline
\end{tabular}

Berdasarkan Tabel 1 didapatkan informasi bahwa rata-rata perusahaan manufaktur yang terdaftar di BEI 2016 dan sebelumnya telah membayarkan dividen 3 tahun berturut-turut memiliki waktu ketahanan untuk tetap membayarkan dividen selama 5 tahun, waktu ketahanan yang paling singkat adalah 1 tahun, dan waktu maksimal perusahaan bertahan selama 7 tahun. Adapun analisis karakteristik semua variabel ditunjukkan Tabel 2.

Tabel 2. Analisis Karakteristik Setiap Variabel

\begin{tabular}{lcccc}
\hline Prediktor & Kategori & \multicolumn{2}{c}{ Status } & Presentase \\
& & $\mathbf{0}$ & $\mathbf{1}$ & \\
\hline Likuiditas & $<200 \%(1)$ & 16 & 15 & $50 \%$ \\
& $>200 \%(2)$ & 25 & 6 & $50 \%$ \\
\hline Leverage & $>90 \%(1)$ & 3 & 3 & $9,68 \%$ \\
& $<90 \%(2)$ & 38 & 18 & $90,32 \%$ \\
\hline Profitabilitas & $<5.98 \%(1)$ & 13 & 16 & $46,77 \%$ \\
& $>5.98 \%(2)$ & 28 & 5 & $53,23 \%$ \\
\hline FCF & negatif (1) & 15 & 8 & $37,10 \%$ \\
& positif (2) & 26 & 13 & $62,90 \%$ \\
\hline Size & $25-27(1)$ & 9 & 3 & $19,36 \%$ \\
& $28-30(2)$ & 20 & 16 & $58,06 \%$ \\
& $31-33(3)$ & 12 & 2 & $22,58 \%$ \\
\hline
\end{tabular}

Berdasarkan Tabel 2, mayoritas perusahaan memiliki size diantara 28-30. Presentase perusahaan dengan likuiditas (current ratio) yang kurang $(<200 \%)$ sama dengan presentase perusahaan berlikuiditas tinggi (>200\%). Perusahaan dengan profitabilitas (return on asset) bernilai rendah $(<5,98 \%)$ dan tinggi $(>5,98 \%)$ tidak berbeda jauh. Presentasi FCF (Free Cash Flow), menunjukkan arus kas masuk (arus kas hasil operasi) lebih besar daripada arus kas keluar pembelian asset tetap) sebesar 62,90\%. Selain itu, sebagian besar perusahaan tersebut memiliki memiliki ekuitas yang lebih besar daripada hutang jangka panjang atau hutang tidak lancar yang ditunjukkan oleh variabel leverage.

\subsection{Plot Fungsi survival dan Uji Log-Rank}

Plot kurva fungsi survival digunakan untuk mengestimasi fungsi ketahanan dari masingmasing variabel. Estimasi kurva fungsi survival ditunjukkan pada 


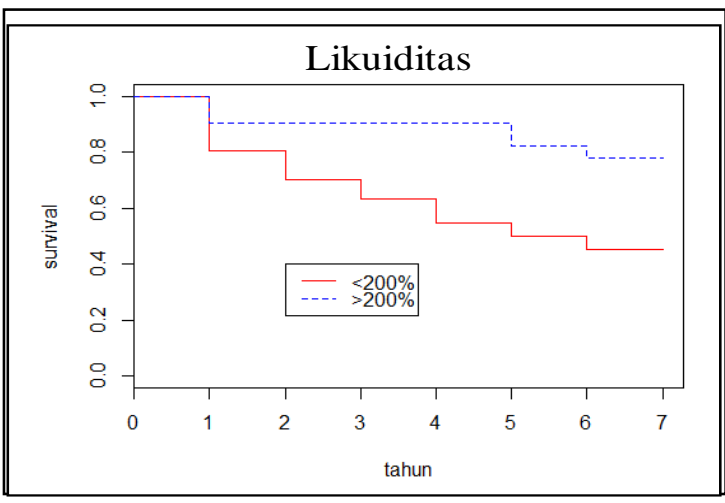

(a)

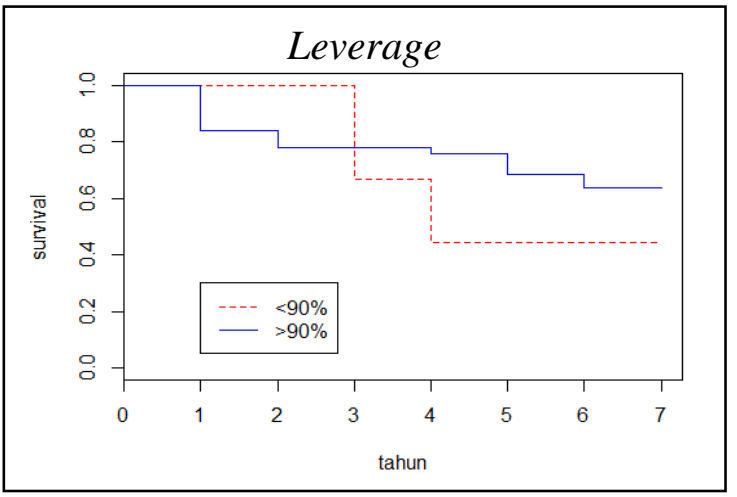

(b)

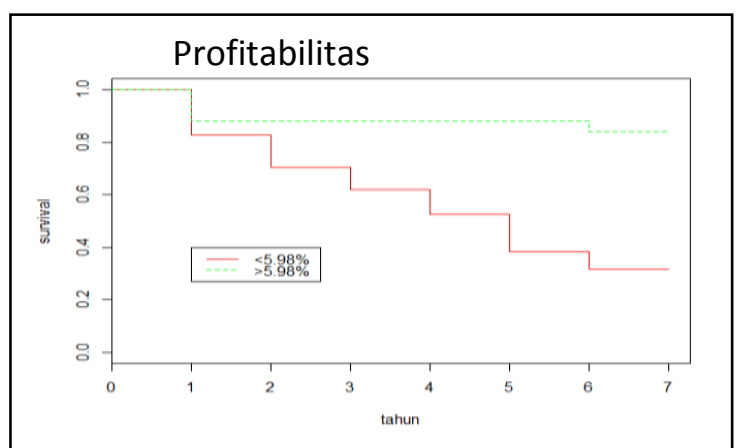

(c)

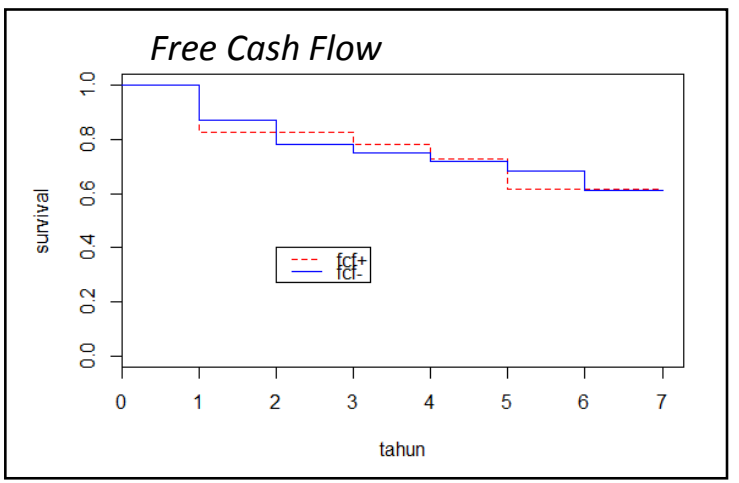

(d)

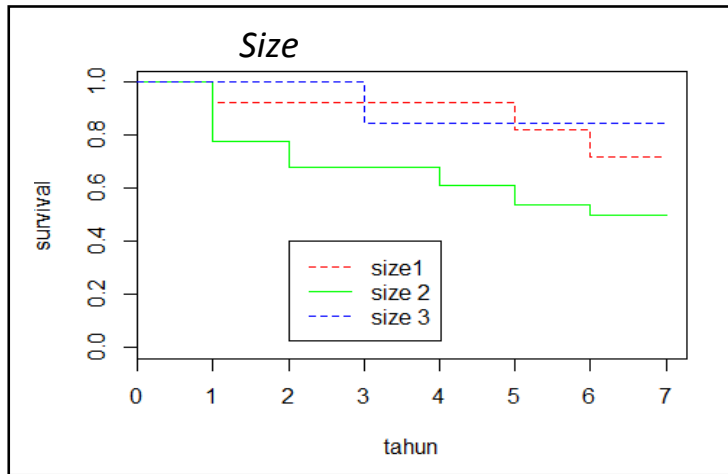

(e)

Gambar 1 Plot Fungsi Survival Setiap Variabel

Berdasarkan Gambar 2 dapat diketahui bahwa (a) dan (c) dengan kategori tinggi memiliki kurva survival yang cenderung konstan berada di atas. Sedangkan untuk (b) dan (e) memiliki kurva survival yang tidak konstan berada di atas atau di bawah sedangkan (d) terlihat berimpit. Selanjutnya, untuk mengetahui perbedaan yang signifikan pada kurva survival antar kelompok pada masing-masing variabel dilakukan uji Log-Rank. Berikut hasil uji Log-Rank dari setiap variabel. 
Tabel 3. Uji Log Rank

\begin{tabular}{lccc}
\hline Variabel & $\begin{array}{c}\text { Log- } \\
\text { Rank }\end{array}$ & df & p-value \\
\hline Likuiditas & 6,6 & 1 & 0,01 \\
\hline Leverage & 0,7 & 1 & 0,397 \\
\hline Profitabilitas & 13,1 & 1 & 0,00029 \\
\hline FCF & 0 & 1 & 0,975 \\
\hline Size & 4,9 & 2 & 0,0867 \\
\hline
\end{tabular}

Berdasarkan hasil uji Log-Rank pada Tabel 3 diperoleh bahwa p-value dari leverage, FCF, dan size lebih besar dari 0,05 sehingga dapat disimpulkan bahwa tidak ada perbedaan kurva survival antar kelompok dalam variabel tersebut, artinya peluang survivalnya cenderung sama untuk masing-masing kategori. Sementara itu, variabel likuiditas dan profitabilitas terdapat perbedaan yang signifikan antara kurva survival, sehingga dapat disimpulkan bahwa variabel likuiditas dan profitabilitas memiliki peluang survival yang berbeda antar setiap kelompok atau kategori. Hal ini dapat diartikan bahwa perusahaan perusahaan yang memiliki likuiditas dan profitabilitas tinggi dapat kontinyu untuk membagikan dividen.

\subsection{Pengujian Asumsi Proportional Hazard}

Pengujian asumsi proportional hazard bertujuan untuk mengetahui variabel mana saja yang memenuhi asumsi proportional hazard. Berikut ini adalah hasil uji asumsi menggunakan dua metode tersebut pada setiap variabel dengan menggunakan program R dan SAS:

\subsubsection{Uji Asumsi Proportional Hazard Menggunakan Goodness of Fit (GOF)}

Pengujian asumsi dilakukan dengan program R. Metode ini menghasilkan $p$-value untuk setiap faktor. Berikut output uji asumsi untuk setiap variabel:

Tabel 4. Pengujian Asumsi Proportional Hazard dengan GOF

\begin{tabular}{lccl}
\hline Variabel & Korelasi & $\boldsymbol{p}$-value & Keputusan \\
\hline Likuiditas 2 & 0,1686 & 0,4849 & Terima $H_{0}$ \\
Leverage 2 & $-0,4191$ & 0,1202 & Terima $H_{0}$ \\
Profitabilitas 2 & $-0,5402$ & 0,0239 & Tolak $H_{0}$ \\
FCF 2 & 0,0879 & 0,6831 & Terima $H_{0}$ \\
size 2 & $-0,2447$ & 0,2508 & Terima $H_{0}$ \\
size 3 & $-0,1547$ & 0,5239 & Terima $H_{0}$ \\
\hline
\end{tabular}

Berdasarkan Tabel 4 diketahui bahwa variabel profitabilitas diduga tidak memenuhi asumsi proportional hazard karena p-value 0,0239 kurang dari $\alpha=0,05$ sehingga diperoleh keputusan tolak $H_{0}$. 


\subsubsection{Uji Asumsi Proportional Hazard Menggunakan Time-Dependent Variable}

Uji asumsi PH menggunakan time-dependent variable digunakan untuk menguatkan keputusan tersebut, akan dilakukan. Berikut tabel hasil uji asumsi dengan time-dependent variable menggunakan program SAS:

Tabel 5. Pengujian Asumsi Proportional Hazard dengan Time Dependent Variable

\begin{tabular}{lccl}
\hline Variabel & Chi-Square & p-value & Keputusan \\
\hline Likuiditas $(2) \times g(t)$ & 0,0616 & 0,8040 & Terima $H_{0}$ \\
Leverage $(2) \times g(t)$ & 2,6852 & 0,1013 & Terima $H_{0}$ \\
Profitabilitas $(2) \times g(t)$ & 3,5991 & 0,0578 & Tolak $H_{0}$ \\
FCF $(2) \times g(t)$ & 0,0650 & 0,7988 & Terima $H_{0}$ \\
Size $\times g(t)$ & 0,1377 & 0,7105 & Terima $H_{0}$ \\
\hline
\end{tabular}

Sesuai Tabel 5 diperoleh keputusan yang sama dengan uji GOF dimana hanya variabel profitabilitas yang tidak memenuhi asumsi proportional hazard dengan $\alpha$ sebesar 0,1 .

Berdasarkan kedua uji asumsi diperoleh kesimpulan bahwa variabel likuiditas, leverage, FCF, dan size memenuhi asumsi proportional hazard sedangkan variabel profitabilitas tidak memenuhi asumsi proportional hazard. Oleh karena itu akan digunakan model Cox nonproportional yakni model Cox proportional hazard dengan time-dependent variable atau biasa disebut dengan Cox extended.

\subsection{Pembentukan Model Cox Extended}

Model Cox dengan time-dependent variable adalah perluasan dari model Cox proportional hazard ketika terdapat variabel yang tidak memenuhi asumsi proportional hazard. Variabel yang tidak memenuhi asumsi proportional hazard yaitu variabel profitabilitas, sehingga variabel profitabilitas diinteraksikan dengan fungsi waktu $\log (t)$ dan fungsi heaviside. Berikut hasil estimasi parameter model Cox dengan time-dependent variable dengan fungsi waktu dan fungsi heaviside.

\subsubsection{Estimasi Parameter Model Cox Extended dengan Fungsi Waktu}

Mencari estimasi parameter model Cox extended menggunakan Maximum Partial Likelihood Estimation (MPLE). Berikut hasil estimasi parameter model Cox extended dengan program SAS:

Tabel 6. Estimasi Parameter Model Cox Extended dengan Fungsi Waktu

\begin{tabular}{lccc}
\hline Variabel & $\begin{array}{c}\text { Estimasi } \\
\text { Parameter }\end{array}$ & Chi-Square & p-value \\
\hline Likuiditas (2) & $-0,52094$ & 0,6986 & 0,4033 \\
Leverage (2) & $-0,68730$ & 0,9782 & 0,3226 \\
Profitabilitas (2) & $-0,29786$ & 0,1659 & 0,6838 \\
FCF(2) & 0,12289 & 0,0708 & 0,7902
\end{tabular}




\begin{tabular}{lccc} 
size $(2)$ & 0,31460 & 0,2023 & 0,6529 \\
size $(3)$ & $-1,32530$ & 1,6704 & 0,1962 \\
Profitabilitas $(2) \times \log (t)$ & $-0,80705$ & 3,5991 & 0,0578 \\
\hline \multicolumn{2}{r}{ Likelihood Ratio } & 22,9330 & 0,0018 \\
\hline
\end{tabular}

Berdasarkan Tabel 6 diperoleh bentuk model Cox extended dengan menggunakan fungsi waktu yakni sebagai berikut.

Model Cox extended:

$$
\begin{aligned}
\widehat{h}(t, x(t))= & \widehat{h_{0}}(t) \exp (-0,52094 \text { likuiditas }(2)-0,68730 \text { leverage }(2) \\
& -0,29786 \text { profitabilitas }(2)+0,12289 \mathrm{FCF}(2) \\
& +0,31460 \text { size }(2)-1,32530 \operatorname{size}(3) \\
& -0,80705 \text { (profitabilitas }(2) \times \log (t)))
\end{aligned}
$$

dengan, $t=$ lama perusahaan bertahan membagikan dividen

Selanjutnya, dengan pengujian serentak menggunakan likelihood ratio diperoleh $p$-value sebesar 0,0018. Digunakan $\alpha$ sebesar 0,05 dan didapatkan keputusan tolak $H_{0}$ yang artinya terdapat minimal satu variabel yang yang signifikan mempengaruhi durasi waktu antara perusahaan mengalami financial distress dan kemunculan omisi pembayaran dividen. Kemudian, dilakukan uji parsial unuk mengetahui variabel yang signifikan. Berdasarkan uji chi-square, diperoleh variabel profitabilitas $(2) \times \log (t)$ signifikan mempengaruhi durasi waktu antara perusahaan mengalami financial distress dan kemunculan omisi pembayaran dividen. Selanjutnya mengestimasi parameter untuk variabel signifikan yakni profitabilitas $(2) \times \log (t)$ sebagai berikut

Tabel 7. Estimasi Parameter Model Cox Extended Signifikan Fungsi Waktu

\begin{tabular}{cccc}
\hline Variabel & $\begin{array}{c}\text { Estimasi } \\
\text { Parameter }\end{array}$ & Chi-Square & p-value \\
\hline Profitabilitas $(2) \times \log (t)$ & $-1,01921$ & 8,1990 & 0,0042 \\
\hline
\end{tabular}

Model baru Cox extended untuk variabel yang signifikan dengan fungsi waktu:

$$
\widehat{h}(t, x(t))=\widehat{h_{0}}(t) \exp (-1,01921(\operatorname{profitabilitas}(2) \times \log (t)))
$$

\subsubsection{Estimasi Parameter Model Cox Extended dengan Fungsi Heaviside}

Jika dilihat dari kurva Kaplan-Meier untuk variabel profitabilitas pada Gambar 2, kurva survival Kaplan-Meier pada kelompok profitabilitas $>5,98 \%$ turun paling besar pada tahun ke 1 dan kemudian konstan sampai tahun ke 6. Sehingga fungsi heaviside yang digunakan sebagai berikut

$$
g(t)=\left\{\begin{array}{l}
1 \text { jika } t<1 \text { tahun } \\
0 \text { jika } t>1 \text { tahun }
\end{array}\right.
$$


Berikut ini estimasi parameter model Cox extended dengan menggunakan fungsi heaviside.

Tabel 8. Estimasi Parameter Model Cox Extended dengan Fungsi Heaviside

\begin{tabular}{lccc}
\hline Variabel & $\begin{array}{c}\text { Estimasi } \\
\text { Parameter }\end{array}$ & Chi-Square & p-value \\
\hline Likuiditas (2) & $-0,54280$ & 0,7562 & 0,3845 \\
Leverage (2) & $-0,66782$ & 0,9226 & 0,3368 \\
Profitabilitas (2) & $-0,04319$ & 0,0034 & 0,9535 \\
FCF (2) & 0,11509 & 0,0619 & 0,8036 \\
Size (2) & 0,29022 & 0,1718 & 0,6785 \\
Size (3) & $-1,35021$ & 1,7315 & 0,1882 \\
Profitabilitas $(2) \times g(t)$ & 0 & - & - \\
Profitabilitas $(2) \times g(t)$ & $-1,40873$ & 5,0737 & 0,0243 \\
\hline \multicolumn{1}{c}{ Likelihood Ratio } & 24,9155 & 0,0008 \\
\hline
\end{tabular}

Sehingga model Cox extended dengan fungsi heaviside adalah:

$$
\begin{aligned}
\widehat{h}(t, x(t))= & \widehat{h_{0}}(t) \exp (-0,54280 \text { likuiditas }(2)-0,66782 \text { leverage }(2) \\
& -0,04319 \text { profitabilitas }(2)+0,11509 \mathrm{FCF}(2) \\
& -0,29022 \text { size }(2)-1,35021 \text { size }(3) \\
& -1,40873 \text { (profitabilitas }(2) \times \mathrm{g}(t)))
\end{aligned}
$$

Hasil dari pengujian serentak menggunakan likelihood ratio, diperoleh p-value sebesar 0,0008. Digunakan $\alpha$ sebesar 0,05 dan didapatkan keputusan tolak $H_{0}$ yang artinya terdapat minimal satu variabel yang yang signifikan mempengaruhi durasi waktu antara perusahaan mengalami financial distress dan kemunculan omisi pembayaran dividen. Kemudian, dilakukan uji parsial unuk mengetahui variabel yang signifikan. Berdasarkan uji chi-square, dengan menggunakan $\alpha$ sebesar 0,05 didapat variabel yang signifikan yaitu variabel profitabilitas $(2) \times g(t)$. Berikut estimasi parameter dari variabel yang signifikan fungsi heaviside.

Tabel 9. Estimasi Parameter Model Cox Extended Signifikan Fungsi Heaviside

\begin{tabular}{cccc}
\hline Variabel & $\begin{array}{c}\text { Estimasi } \\
\text { Parameter }\end{array}$ & Chi-Square & $\boldsymbol{p}$-value \\
\hline profitabilitas $(2) \times g(t)$ & $-1,55972$ & 8,8184 & 0,0030 \\
\hline
\end{tabular}

Model Cox extended yang terbentuk:

$\widehat{h}(t, x(t))=\widehat{h_{0}}(t) \exp (-1,55972$ profitabilitas $\times g(t))$

\subsection{Pemilihan Model Cox Extended Terbaik}

Pemilihan model Cox extended terbaik dilakukan dengan cara membandingkan nilai AIC pada masing-masing variabel signifikan fungsi waktu dan fungsi heaviside. Model terbaik ialah model yang memiliki nilai $A I C$ terkecil. 
Tabel 10. Perbandingan Akurasi Model Cox Extended

\begin{tabular}{lc}
\hline Model Cox Extended & Nilai AIC \\
Fungsi Waktu & 148,310 \\
Fungsi Heaviside & 145,750 \\
\hline
\end{tabular}

Berdasarkan Tabel 10, nilai AIC model Cox extended dengan fungsi heaviside lebih kecil daripada fungsi waktu, sehingga model Cox extended terbaik adalah model Cox extended dengan fungsi Heaviside.

\subsection{Pembahasan Hasil Penelitian}

Sebanyak 62 perusahaan yang diambil data rasio keuangannya berupa likuiditas (current ratio), leverage (long-term debt to equity), profitabilitas (return on asset), free cash flow, dan size dengan faktor yang diduga tersebut, diperoleh bentuk model Cox extended sebagai berikut. Model Cox extended dengan fungsi waktu $g(t)=\log (t)$ :

$$
\begin{aligned}
\hat{h}(t, x(t))= & \widehat{h_{0}}(t) \exp (-0,52094 \text { likuiditas }(2)-0,68730 \text { leverage }(2) \\
& -0,29786 \text { profitabilitas }(2)+0,12289 \mathrm{FCF}(2) \\
& +0,31460 \text { size }(2)-1,32530 \text { size }(3) \\
& -0,80705 \text { (profitabilitas }(2) \times \log (t)))
\end{aligned}
$$

Kemudian dilakukan pengujian pada setiap variabel dengan uji serentak yang ditunjukkan pada Tabel 6 untuk mengetahui variabel mana yang berpengaruh signifikan dalam model Cox extended dengan fungsi waktu $g(t)=\log (t)$. Diperoleh kesimpulan bahwa hanya variabel profitabilitas $(2) \times \log (t)$ yang berpengaruh signifikan terhadap model. Selanjutnya, variabel yang tidak berpengaruh signifikan dikeluarkan dari model.

Model baru Cox extended untuk variabel yang signifikan dengan fungsi waktu:

$$
\left.\widehat{h}(t, x(t))=\widehat{h_{0}}(t) \exp (-1,01921 \text { (profitabilitas }(2) \times \log (t))\right)
$$

Model Cox extended dengan fungsi Heaviside:

Model Cox extended dengan fungsi heaviside adalah

$$
\begin{aligned}
\widehat{h}(t, x(t))= & \widehat{h_{0}}(t) \exp (-0,54280 \text { likuiditas }(2)-0,66782 \text { leverage (2) } \\
& -0,04319 \text { profitabilitas }(2)+0,11509 \mathrm{FCF}(2) \\
& -0,29022 \text { size }(2)-1,35021 \text { size }(3) \\
& -1,40873 \text { (profitabilitas }(2) \times \mathrm{g}(t)))
\end{aligned}
$$

Selanjutnya, dilakukan uji parsial unuk mengetahui variabel yang signifikan. Berdasarkan uji chi-square, dengan menggunakan $\alpha$ sebesar 0,05 didapat variabel yang signifikan yaitu variabel profitabilitas $\times g(t)$. Dari Tabel 8 diperoleh Model Cox extended yang terbentuk:

$$
\widehat{h}(t, x(t))=\widetilde{h_{0}}(t) \exp (-1,55972 \text { profitabilitas }(2) \times g(t))
$$

Setelah diperoleh model, dilakukan pemilihan model terbaik dari dua model yang signifikan dengan menggunakan nilai AIC. Berdasarkan Tabel 10 diperoleh model terbaik adalah 
model Cox extended yang signifikan dengan fungsi heaviside. Nilai interpretasi dari model yang dipilih adalah untuk setiap perusahaan dengan tingkat profitabilitas tinggi $(>5,98 \%)$, memiliki risiko mengalami dividen omisi sebesar $\exp (-1,55972)=0,2120$. Sehingga setiap perusahaan dengan rasio profitabilitas tinggi memiliki risiko menghapuskan pembagian dividen sebesar $21 \%$ lebih kecil daripada perusahaan dengan rasio profitabilitas kecil.

\section{Simpulan}

Berdasarkan hasil analisis data pada variabel-variabel yang mempengaruhi durasi waktu antara perusahaan mengalami financial distress dan kemunculan dividen omisi pada perusahaan manufaktur 2016 adalah variabel likuiditas dan profitabilitas. Model terbaik dari durasi waktu antara perusahaan mengalami financial distress hingga muncul omisi pembayaran dividen adalah model time-dependent variable dengan fungsi heaviside. Model terbaik dengan variabel yang signifikan:

$$
\widehat{h}(t, x(t))=\widehat{h_{0}}(t) \exp (-1,55972 \text { profitabilitas }(2) \times g(t))
$$

dimana perusahaan dengan rasio profitabilitas tinggi dalam waktu 7 tahun memiliki risiko mengalami dividen omisi sebesar $21 \%$ lebih kecil daripada perusahaan dengan rasio profitabilitas rendah.

\section{Daftar Pustaka}

[1] Emrinaldi, "Analisis pengaruh praktek tata kelola perusahaan (corporate governance) terhadap kesulitan keuangan perusahaan (financial distress)," Jurnal Bisnis dan Akuntansi, 9, 1, 2007.

[2] Fathurrahman, M., "Pemilihan model regresi terbaik menggunakan metode akaike's information criterion dan schwart information criterion," Jurnal Informatika Mulawarman, 4, 3, 37-41, 2009.

[3] Hanafi, L., M.P. Endah R., dan Puspita, G. M., "Penyelesaian numerik untuk menentukan nilai optimal pada american option dengan metode beda hingga fully implisit dan cranknicolson", Limits, 7, 2, 1-12, 2010.

[4] Kasmir, Analisis Laporan Keuangan, PT. Rajawali, Jakarta, 2014.

[5] Kleinbaum, D.G dan Klein, M., Survival Analysis a Self-Learning Text, Third Edition, Springer, New York, 2011.

[6] LeClere, M. J., "The occurance and timing of events : aplikasi analisis survival pada studi financial distress," Jurnal Akuntansi, 19, 89-158, 2000.

[7] Murhadi, W.R., Analisis Laporan Keuangan Proyeksi dan Valuasi Saham, Salemba 
Empat, Jakarta, 2013.

[8] Sielvia, A. Z., "Pengaruh dividen inisiasi dan dividen omisi terhadap return saham di Bursa Efek Indonesia, " Jurnal Siasat Bisnis, 13, 2, 113-128, 2009. 